\title{
Cuatro vidas árabes de Aristóteles
}

\author{
Four arabic lives of Aristotle \\ Rafael Ramón GUERRERO \\ Universidad Complutense
}

\section{Resumen}

Se ofrece a continuación una versión española de cuatro de las vidas árabes de Aristóteles.

Palabras clave:Vidas árabes de Aristóteles, Ibn al-Nadîm, al-Mubaššir b. Fâtik, Ibn al-Qiftî, Ibn Abî Usaybi'a.

\begin{abstract}
:
In this article, I will present a Spanish version of four Arabic lives of Aristotle. Keywords: The Arabic Lives of Aristotle, Ibn al-Nadîm, al-Mubaššir b. Fâtik, Ibn al-Qiftî, Ibn Abî Usaybi‘a.
\end{abstract}

Con ocasión de la celebración del 2400 aniversario del nacimiento de Aristóteles, celebrado en la ciudad griega de Tesalónica, un grupo de arqueólogos ha anunciado el descubrimiento de la tumba de Aristóteles en su ciudad natal, Estagira, citando como un punto de apoyo para tal hipótesis una vida árabe de Aristóteles ${ }^{1}$. Este hecho y la propia conmemoración que se celebra este año, me ha traído a la memoria un viejo proyecto, abandonado antes de tiempo, que emprendí hace muchos años con mi querido profesor José Antonio García-Junceda. Fruto de ese proyecto fueron dos publicaciones que hicimos conjuntamente, la segunda cuando ya José Antonio había fallecido². El resto de las vidas árabes de Aristóteles ya las había traducido, a

\footnotetext{
${ }^{1}$ ABC, 26-05-2016: "En la excavación se encontraron objetos de cerámica, y más de cincuenta monedas que demuestran que la tumba es de la época de Alejandro Magno. Además, fuentes literarias señalan que los restos de Aristóteles están ahí enterrados: se basan en el manuscrito 257 de la Biblioteca Marciana de Venecia y en una biografía árabe de Aristóteles". ABC, 27-05-2016: El Prof. Tomás Calvo afirma que "los arqueólogos se han apoyado en una biografía de Aristóteles del siglo IV d. C. que conocemos en una traducción árabe del siglo VIII muy tardía, en la que se cuenta que los estagiritas acudieron a Eubea a solicitar las cenizas del filósofo, porque había muerto allí, y que las llevaron a la ciudad natal con gran solemnidad".

${ }^{2}$ J. A. García-Junceda - R. Ramón Guerrero: "La vida de Aristóteles de Ibn Ŷulŷul", Anuario del
} 
la espera de mejor ocasión para su divulgación. Me parece que ahora es el momento oportuno de darlas a la luz pública para que el lector español pueda tener acceso a ellas. Recupero aquí parte de lo que escribimos entonces como introducción a esta publicación de las cuatro vidas de Aristóteles que ofrezco a continuación.

Las biografías árabes de Aristóteles se sirvieron de la llamada Vida de Ptolomeo ${ }^{3}$, atribuida a Ptolomeo Chennos, autor casi desconocido de la escuela peripatética que debió vivir a fines del siglo I y comienzos del siglo II, perdida en su texto griego ${ }^{4}$ y conservada en algunos resúmenes, como la Vita Marciana, la Vita Vulgata, la Vita latina en la siríaca Vita de Ammonio y en las biografías árabes de Ibn al-Nadîm (m. ca. 995), al-Mubaššir ibn Fâtik (s. XI), al-Qiftî (m. 1248) e Ibn Abî Usaybi‘a (m. 1270), en las que lo llaman Ptolomeo al-Garîb (el Extranjero). Todas estas "vidas" árabes han sido estudiadas y traducidas al inglés, más o menos íntegramente, por Ingemar Düring 5 .

Además de estas cuatro "vidas" árabes de Aristóteles, existen algunas otras referencias biográficas al filósofo griego, de las que esos cuatro autores toman datos para la construcción de su biografía de Aristóteles. Entre quienes ofrecen estas referencias está el médico y traductor nestoriano Hunayn b. Ishâq (m. 873), autor de un libro titulado Adab al-falâsifa ${ }^{6}$, traducido al castellano en el siglo XIII con el título El libro de los buenos proverbios ${ }^{7}$, obra que consta de tres partes: las dos primeras

Departamento de Historia de la Filosofia y de la Ciencia, UAM, Curso 1984/85, pp. 109-123. J. A. García-Junceda (†) - R. Ramón Guerrero: "La vida de Aristóteles de Abû Sulaymân al-Siŷistânî", Anales del Seminario de Historia de la Filosofia, UCM, 7 (1989) 25-36.

${ }^{3}$ M. Plezia: "De Ptolemaei Vita Aristotelis", en Aristoteles: Werk und Wirkung, vol. I (Aristoteles und seine Schule), ed. Jürgen Wiesner, Berlin, Walter de Gruyter, 1985, pp. 1-11.

${ }^{4}$ Cf I. Düring, "Ptolomy's Vita Aristotelis Rediscovered", in R. B. Palmer, R. Hamerton-Kelly (eds.): Philomathes. Studies and essays in the humanities in memory of Philip Merlan, The Hague, Nijhoff, 1971, pp. 264-269. El autor concluye en la p. 269: «Después de la dedicatoria de la carta sigue el texto de la biografía, el testamento, los aforismos, y el catálogo de los escritos de Aristóteles, fols. 11a 18a. El texto es palabra por palabra casi idéntico con el reproducido por Ibn Abî Usaybi‘a». H. B. Gottschalk: "The earliest Aristotelian commentators", in R. Sorabji (ed.): Aristotle Transformed. The Anciant Commentators and their Influence, Ithaca, N.Y. Cornell University Press, 1990 pp. 56-57, n. 5 señala que Marian Plezia le informó que él y Józef Bielawski, muertos en 1996 y 1997 respectivamente, estaban preparando una edición de esta Vida, conservada en un manuscrito en Estambul Aya Sofya, ${ }^{\circ}$ 4833. Desgraciadamente, esta edición nunca ha visto la luz.

${ }^{5}$ Aristotle in the Ancient Biographical Tradition, Studia Graeca et Latina Gothobergensia, Göteborg, 1957, pp. 183-246. Cf. también A.-H. Chroust: Aristotle. New light on his life and on some of his lost works, London, Routledge \& Kegan Paul, 1973, pp 54-72. D. Gutas: "The spurious and the authentic in the Arabic lives of Aristotle", en Pseudo-Aristotle in the Middle Ages. The Theology and others Texts, ed. by J. Kraye, W.F. Ryan and C. B. Schmitt, London, The Warburg Institute, University of London, 1986, pp. 15-36.

${ }^{6}$ Adab al-falâsifa (Sentences des Philosophes), édition critique, notes et introduction par A. Badawi, Kuwait, 1985.

${ }^{7}$ The Libro de los buenos proverbios. A Critical Edition by H. Sturm, Lexington, The University Press of Kentucky, 1971. 
son un anecdotario y un repertorio de historias, epístolas y dichos de los filósofos griegos, tomados por lo general de florilegios anteriores o de la tradición oral, por lo que no hay en ella propiamente una vida de Aristóteles, sino dichos puestos en su boca. La tercera parte narra la muerte de Alejandro Magno, personaje que tuvo una gran popularidad en el mundo árabe ${ }^{8}$.

El hijo del anterior, Ishâq b. Hunayn (m. 910), llevó a cabo una amplia labor de traducción al árabe de obras griegas, bien directamente del griego o a través del siríaco, especialmente de textos aristotélicos. Posiblemente, fue el que introdujo en el mundo árabe los excerpta siríacos de la Vida de Ptolomeo, de los que no se han conservado ningún fragmento. Pero sí ha llegado hasta nosotros un libro suyo titulado Ta'rîj al-atibbâ' wa-l-Hukamâ' (Historia de los médicos y de los sabios)', escrita posiblemente hacia el año 903, en el que en lugar de ofrecer un repertorio de biografías establece una serie sucesoria de generaciones de médicos, a los que añade algunos filósofos: "Éste es un libro compuesto por Istâq b. Hunayn sobre la cronología de los médicos. Incluyó también a aquellos filósofos que alcanzaron perfección en alguna parte de la medicina" ${ }^{10}$. Presenta la obra como una discusión entre dos personajes, que debaten sobre quién es el médico más antiguo, sobre el origen de la medicina, si es Dios o es el hombre, y cuál es su lugar de origen, Egipto, Grecia, Persia o India. Una de las fuentes de esta obra puede ser el escrito conocido por Historia, Ta'rîj según los textos árabes, atribuida a Juan Filopono, cristiano de Alejandría, citado en los textos árabes posteriores, pero del que no hay constancia que existiera, al menos con ese título. Pudo tratarse de parte de algún tratado histórico de Filopono, hoy desconocido, o bien de alguna obra suya de medicina ${ }^{11}$. También es posible que Ishâq utilizara la traducción árabe que del De sectis de Galeno había hecho su padre Hunayn b. Ishâq ${ }^{12}$. A pesar de ser aquél su objetivo, aparecen en la obra detalles biográficos referentes a algunos autores, como Platón, de quien indica

\footnotetext{
${ }^{8}$ Cf. R. Ramón Guerrero: "El Pseudo-Aristóteles árabe y la literatura didáctico-moral hispana: del Sirr al-asrâr a la Poridat de las poridades", Pensamiento medieval hispano. Homenaje a Horacio Santiago Otero, ed. José M. Soto Rábanos, Madrid, C.S.I.C., 1998, pp. 1037-1051.

${ }^{9}$ Ed. y trad. F. Rosenthal: "Ishaq b. Hunayn's Ta'rih al-atibba”, Oriens, 7 (1954) pp. 55-80

${ }^{10} \mathrm{Ibídem}$, texto árabe p. 61; trad. ingl., p. 72.

${ }^{11}$ Cf. M. Meyerhof: "Joannes Grammatikos (Philoponos) von Alexandrien und die arabische Medizin", Mitteilungen des Deutschen Instituts für ägyptische Altertumskunde in Kairo, 2 (1932) 1-21.

${ }^{12}$ Así cuenta el propio Hunayn su versión de este libro de Galeno: «El Libro de las sectas de Galeno lo tradujo al siríaco, antes que yo, un tal Ibn $\underline{\text { S̆} a h d a ̂ ~ d e ~ a l-K a r j . ~ E r a ~ u n ~ m a l ~ t r a d u c t o r . ~ D e s p u e ́ s, ~ c u a n d o ~ y o ~}$ tenía veinte años más o menos, lo traduje a partir de un manuscrito griego defectuoso para un médico de Ŷundiŷâpûr llamado Sîrîŷu’ b. Qutrub. Al llegar a los cuarenta años mi discípulo Hubayš me pidió que lo corrigiera, pues yo ya disponía de varios manuscritos griegos. He colacionado todos esos manuscritos para establecer un texto correcto. Después he comparado el texto griego así establecido con mi antigua traducción siríaca y la he corregido. Este método es el que sigo en todas mis traducciones». (Hunayn B. Ishâq: "Über die syrischen und arabischen Galen Übersetzungen", ed. G. Bergsträsser, Abhandlungen für die Kunde des Morgenlandes, 17 (Leipzig 1925), II, pp. 4-5.
} 
los años que vivió. Sin embargo, aunque autores posteriores dicen haber tomado de Ishâq que "Aristóteles vivió sesenta y siete años", la única vez que aparece citado Aristóteles en el libro de Ishâq ${ }^{13}$ nada dice de ello, puesto que lo único que se afirma es que Aristóteles fue uno de los filósofos de los que Galeno adquirió conocimiento y es citado junto con los nombres de Apolonio, Zenón el Mayor, Zenón el Joven, Glaucón, Sócrates, Platón, Demócrito y "algunos más".

Los autores de las cuatros vidas basan su biografía en otras diversas fuentes. Por una parte, ellos mismos se citan entre sí: al-Qiftî cita a Ibn al-Nadîm, Ibn Abî Usaybi'a cita también a Ibn al-Nadîm y a al-Mubaššir, etc., lo que demuestra una continuidad y comunidad de las fuentes de información que importa destacar en lo que se refiere a la Vida de Ptolomeo, ya que sirviéndose todos de ella, ninguno manifiesta un mejor o más amplio conocimiento, como parece sería lógico si hubieran dispuesto de un material nuevo. Además de transcribir textos de Hunayn b. Ishâq y de su hijo Ishâq b. Hunayn, copian también de Abû Sulaymân al-Mantiqî al-Siŷistânî (m. 987), autor del Siwân al-hikma (El armario de la sabiduría), conocida hoy sólo por la selección (muntajab) ${ }^{14}$ que de ella hizo 'Umar ibn Sahlân al-Sâw (primera mitad del siglo XII) y por una adición o complemento, realizado por al-Bayhaqî (m. 1169), la Tatimma Siwân al-hikma ${ }^{15}$. Citan también a Abû Dawûd Sulaymân b. Hassân b. Ŷulŷul (m. Córdoba, 994), autor de Tabaqât al-atibbā' wa-l-Hukamâ' (Libro de las generaciones de los médicos y de los sabios) ${ }^{16}$ y a Sấid al-Andalusî (m. Toledo, 1070), quien pasa por ser el primer historiador de la ciencia hispano-árabe en su obra Tabaqât al-umam (Las categorías de las naciones) ${ }^{17}$.

Las fuentes árabes manejadas por los biógrafos islámicos son, por tanto, variadas y diversas. Voy a ofrecer en lo que sigue las vidas de Aristóteles escritas por los cuatro autores $\operatorname{citados}^{18}$.

\footnotetext{
${ }^{13}$ Ed. cit., texto árabe p. 69, línea 6; trad. ingl. p. 79.

${ }^{14}$ Muntakhab Siwân al-hikmah et trois traités, publiés, annotés et préfacés par A. Badawi, Téhéran, 1974. The Muntakhab Siwân al-hikmah of Abū Sulaymān as-Sijistānī, Arabic Text, Introduction and Indices edited by D.M. Dunlop, The Hague, Mouton Publishers, 1979.

${ }^{15}$ Tatimma Siwân al-hikma, ed. M. Shafi, Lahore, Punjab University Publication, 1935. Nueva ed. con el título Ta'rîj hukamâ'al-Islâm por M. Kurd Ali, Damasco, 1946.

${ }^{16}$ Les générations des médecins et des sages, par Ibn Ğulğul al-Andalusí, ed. critique par Fu'âd Sayyid, Le Caire, 1955. Cf. J. Vernet: "Los médicos andaluces en el 'Libro de las generaciones de los médicos' de Ibn Ŷulŷul", en Estudios sobre la Historia de la ciencia medieval, Barcelona-Bellaterra, 1979, pp. 469-486.

${ }^{17}$ Sầid al-Andalusî: Kitâb Tabaqât al-umam, ed. L. Cheikho, Beirut, Imprimerie Catholique, 1912. Nueva ed. H. Bû 'Alwân, Beirut, Dâr al-Talî’a, 1985. Trad. castellana: Libro de las categorías de las naciones, trad. F. Maíllo Salgado, Madrid, Ed. Akal, 1999.

${ }^{18}$ Las traducciones de estas vidas árabes fueron hechas entre 1978 y 1986. Las dejo tal como en su momento fueron realizadas, sin introducir cambio alguno.
} 


\section{La vida de Ibn al-Nadîm}

De la vida de Abû 1-Faraŷ Muhammad b. Ishâq al-Warrâq al-Nadîm ${ }^{19}$ se conoce muy poco. Se sabe que vivió en Bagdad y que fue librero y copista (warrâq). Escribió una obra muy conocida, el Kitâb al-Fihrist (Índice) ${ }^{20}$, completada según el propio autor en el año 987; pretende ser un índice de todos los libros escritos en árabe por árabes y no árabes. Está dividida en diez discursos (maqâlât), siendo el séptimo el dedicado a la filosofía y las ciencias antiguas. La biografía de Aristóteles no se limita a dar noticia de episodios de su vida, sino que también incluye una descripción de sus libros, con expresión de las traducciones árabes realizadas de ellos y de algunos de sus comentarios compuestos por los comentaristas griegos. Doy a continuación la traducción de esta vida, aunque por razones de espacio omito todo lo referente a las obras de Aristóteles ${ }^{21}$.

\section{[345] Noticias de Aristóteles.}

El significado [de su nombre] es el de "amante de la sabiduría". Se ha dicho también "el excelente" (al-fâdil), "el perfecto". Y también se ha dicho "el mejor", "el excelente". Es Aristóteles, hijo de Nicómaco, hijo de Macaón, de los hijos de Esculapio, el que inventó la medicina para los griegos.

Ptolomeo el Extranjero contó lo siguiente: El nombre de su madre era Festias y descendía de Esculapio. Era de una ciudad griega que se llama Estagira. Su padre Nicómaco ejercía la medicina para Filipo, el padre de Alejandro. Fue uno de los discípulos de Platón. Ptolomeo continuó diciendo: Se puso bajo la dirección de Platón por inspiración de Dios Altísimo en el templo de Pition. También dijo: Permaneció aprendiendo durante veinte años y, cuando Platón se ausentó a Sicilia, Aristóteles le sucedió en la sede de la enseñanza.

Se ha dicho que estudió la filosofía después de haber cumplido los treinta años de edad. Fue el más elocuente de los griegos y de sus escritores, el más ilustre de sus sabios después de Platón y el que alcanzó un grado sublime en filosofía y un lugar grandioso

\footnotetext{
${ }^{19}$ Cf. J. W. Fück: "Ibn al-Nadîm”, en Encyclopaedia of Islam, vol. III, edited by B. Lewis, V. L. Ménage, Ch. Pellat and + J. Schacht, Leiden, J. Brill, 1979, pp. 895-896.

${ }^{20}$ Ibn al-Nadîm: Kitâb al-Fihrist, ed. Flügel, Leipzig, Harrassowitz, 1872; la vida de Aristóteles en las pp. 246-252. Nueva edición El Cairo, al-Matba'a al-Rahmâniyya, 1348/1929; la vida de Aristóteles en pp. 345- 352. En mi traducción me atengo a esta edición y cito entre corchetes las páginas correspondientes. Trad. inglesa: Bayard Dodge: The Fihrist of al-Nadim: A Tenth-Century Survey of Islamic Culture, New York, Columbia University Press, 2 vols., 1970; la vida de Aristóteles en el vol. II, pp. 594-606.

${ }^{21}$ Una descripción completa de las listas de las obras de Aristóteles dadas por los biógrafos árabes se halla en F. E. Peters: Aristoteles Arabus. The Oriental Translations and Commentaries on the Aristotelian Corpus, Leiden, J. Brill, 1968.
} 
entre los reyes. Por consejo suyo, Alejandro administraba sus asuntos. Había compuesto para él un conjunto de escritos y de cartas sobre política y otras materias.

Entre ellas está una Epístola sobre política que comienza así: "La frecuencia de tus buenas obras ha anulado la admiración que despiertan, pues han llegado a ser como algo viejo a lo que uno se ha acostumbrado, no como lo nuevo que causa admiración. Tú eres tal como dice la gente. El que te elogia, no miente". Esta misma Epístola dice lo siguiente: "Cuando las desgracias afligen a los hombres, ellos se mueven por lo que despierta su interés; pero cuando alcanzan la seguridad, se inclinan entonces a la avidez y abandonan todo recato de precaución. Por ello, la gente está más necesitada de ley cuando está en situación de seguridad y tranquilidad". También se dice en ella: "Tratad a los enemigos con beneplácito; a los que se han liberado, con perdón; a los confesos, con benevolencia; a los que asaltan, con oposición; a los inicuos, con censura; a los envidiosos, con ira; a los estúpidos, con magnanimidad; a los rebeldes, con rigor; a los perturbadores, con desprecio; a los mordaces, con cautela; los asuntos dudosos, con dilación; los asuntos evidentes, con firmeza; los asuntos problemáticos, con indagación; finalmente, la amistad con los reyes, con la discreción del secreto, con la buena orientación de sus acciones, con elogio y celo, pues lo que les preocupa es la alabanza para ellos, mientras que exigen servidumbre para los demás hombres". Esto es un discurso de extrema sabiduría [346] y elocuencia y de muchas ideas, a pesar de que ha sido traducido de una lengua a otra. ¡Cómo sería en la lengua del que lo expresó!

También se ha dicho que cuando murió Filipo y Alejandro se convirtió en rey y se dirigió a guerrear contra las naciones, Aristóteles se retiró y se hizo asceta. Llegó a Atenas y estableció un lugar para enseñar: es el lugar que está en relación con los filósofos peripatéticos (maššâ 'în). Se dedicó entonces a ocuparse de las necesidades de los hombres, a proteger a los débiles y a restaurar los edificios de la ciudad de Estagira. Sus noticias son muchas. Sólo hemos citado un resumen de ellas.

Aristóteles murió cuando tenía sesenta y seis años, durante los últimos días de Alejandro, aunque se ha dicho que al comienzo del reinado de Ptolomeo Lagos. Teofrasto, hijo de su hermana, le sucedió en la enseñanza.

\section{El testamento de Aristóteles}

[Ptolomeo] el Extranjero dijo: Cuando le llegó la hora de su muerte, [Aristóteles] indicó lo siguiente:

"He designado albacea mío a perpetuidad, para todo lo que he dejado, a Antípatro. Hasta que Nicanor llegue, que Aristómenes, Timarco, Hiparco y Dioteles se ocupen de supervisar lo que haya que realizar y se cuiden de aquellos asuntos de mi familia que así lo requieran, de mi sierva Herpilis, de los otros siervos y esclavos míos y de lo que he dejado. Si Teofrasto puede permanecer con ellos y si le es fácil hacerlo, que se encargue también de ello. 
Hasta que mi hija alcance la madurez, Nicanor se hará cargo de sus asuntos. Si muriera antes de casarse o después de casarse pero sin tener ningún hijo, entonces sus asuntos retornarán a Nicanor, así como los asuntos de mi hijo Nicómaco. El consejo que le doy en esto es que proceda en la administración de lo que hace según crea conveniente y según le convenga.

Si Nicanor muriese antes de casarse mi hija o después de casarse sin tener ningún hijo, y si Nicanor deja en testamento lo que yo he dejado, que sea válido y efectivo. Si Nicanor muere sin hacer testamento y si le es fácil a Teofrasto, me gustaría que ocupase su lugar en el asunto de mi hijo y en los otros asuntos que he dejado; si no quiere, entonces que los albaceas que he nombrado recurran a Antípatro y le consulten lo que han de hacer sobre lo que he dejado y que ejecuten los asuntos según lo que decidan de acuerdo con él.

Que Nicanor y los albaceas me tengan presente en Herpilis, pues ella merece eso de mí, por el cuidado que según he visto puso en servirme y por su desvelo en corresponder a mi alegría. Que se ocupen de todo lo que ella necesite. Si quiere casarse, que no lo haga si no es con un hombre virtuoso. Que se le entreguen, [347] además de lo que ya tiene, un talento de plata, que es igual a ciento veinticinco libras, y tres esclavas entre las que ella prefiera, además de la esclava y del esclavo que ya posee. Si quiere permanecer en Calcis, que habite en mi casa, en la hospedería, que está junto al jardín. Si, por el contrario, prefiere residir en la ciudad de Estagira, que viva en la casa de mis padres. Sea cual fuere la casa que elija, que los albaceas tomen para ella todo lo que diga necesitar.

En cuanto a mi familia y a mi hijo, no tengo necesidad de dejarles testamento para su protección y para el cuidado de sus asuntos. Que Nicanor cuide del joven esclavo Myrmex hasta que regrese a su país con todos sus bienes, de la manera que desee. Que mi esclava Ambracis sea emancipada y, si después de manumitida quiere permanecer al servicio de mi hija hasta que se case, que se le entreguen quinientos dracmas y su joven esclava. Que a Tales se le entreguen la joven que recientemente hemos adquirido, uno de nuestros jóvenes esclavos y mil dracmas. Que a Simos se le entregue el precio de un esclavo que pueda comprar para sí, distinto del joven esclavo cuyo precio ya se le había entregado y que se le dé además lo que acuerden los albaceas.

Cuando mi hija se case, que sean emancipados mis jóvenes esclavos Tacón, Filón y Herpilis ${ }^{22}$. Que el hijo de Herpilis no sea vendido ni ningún otro de mis esclavos que han estado a mi servicio, sino que permanezcan sirviendo hasta que alcancen la madurez de los hombres; cuando lleguen a la edad adulta, que sean emancipados; lo que se les haya de dar, que se haga según lo que merezcan, si Dios Altísimo quiere".

\footnotetext{
${ }^{22}$ Así en el texto. En los otros biógrafos árabes figura el nombre de Olimpio.
} 
Del puño y letra de Ishâq [b. Hunayn] y con sus propias palabras he visto lo siguiente: "Aristóteles vivió sesenta y siete años"23.

\section{La vida de al-Mubaššir b. Fâtik}

Otra de las obras en las que aparece una biografía de Aristóteles es la obra del historiador, filósofo y bibliófilo siro-egipcio Abû 1-Wafầ' al-Mubaššir b. Fâtik ${ }^{24}$ (fl. ca. 1050), titulada Mujtâr al hikam, o sea, Selección de sentencias, traducida al castellano en la corte de Alfonso X el Sabio, por traductor anónimo hacia 1257, con el título Los bocados de oro o Bonium, y luego al latín con el título Liber philosophorum moralium antiquorum, al provenzal, al francés y al inglés ${ }^{25}$. En este libro su autor expone el viaje del rey en busca de la sabiduría y ésta la encuentra en las vidas y dichos de los filósofos. La vida de Aristóteles ocupa las páginas 178 a 183 de la edición de A. Badawi, de la que realizo la siguiente traducción.

\section{[178] Noticias de Aristóteles}

El significado del nombre griego de Aristóteles es "el más perfecto", "el excelente". El nombre de su padre, Nicómaco, quiere decir "contendiente victorioso". Era un hombre hábil en medicina. [179] Aristóteles le nació en la ciudad llamada Estagira, en la región de la Calcídica, en la provincia de Tracia. El nombre de su madre era Festias. Su padre Nicómaco era médico de Amintas, padre de Filipo, padre de Alejandro. El linaje de su padre Nicómaco remontaba a Esculapio, estirpe excelente entre los griegos. El linaje de su madre también remontaba a Esculapio.

Cuando tenía ocho años su padre lo llevó a Atenas, conocida por "tierra de los sabios". Se instaló en el liceo de allí, donde su padre lo reunió con los poetas, oradores y gramáticos, permaneciendo aquí durante nueve años, aprendiendo de ellos. El nombre de esta ciencia para ellos era "la circundante" (al-muhît), es decir, la ciencia

\footnotetext{
${ }^{23}$ Sigue a continuación un amplio discurso sobre el orden de los libros de Aristóteles sobre Lógica, Física, Metafísica y Ética.

${ }^{24}$ F. Rosenthal: "al-Mubashshir b. Fâtik, Abû 1-Wafầ", en Encyclopaedia of Islam Vol. 7, edited by C. E. Bosworth, E. Van Donzel, W.P. Heinrichs and the late Ch. Pellat, assisted by F. Tn. Dijkema (pp. 1-384), P. J. Bearman (pp. 385-1058) y Mme S. Nurit, 1993, pp. 282-283.

${ }^{25}$ Edición del texto árabe por A. Badawi: Los bocados de oro (Mujtâr al-hikam), Madrid, Instituto Egipcio de Estudios Islámicos, 1958. La edición de la versión castellana medieval la realizó H. Knust en Tubingen, 1879. Hay nueva edición: Bocados de oro, Kritische Ausgabe des altspanischen Textes von Mechthild Crombach, Bonn, Romanischer Seminar der Universität Bonn, 1971. Cf. Rosenthal, F.: "Al-Mubashshir Ibn Fâtik. Prolegomena to an Abortive Edition”, Oriens, 13-14 (1961) 132-158. Hay edición de la traducción castellana de 1495, editada en Sevilla, en la siguiente página de la Biblioteca Saavedra Fajardo: http://www.saavedrafajardo.org/Archivos/LIBROS/Libro0787.pdf. Cf. también A. Rivera García: "Bocados de oro y la literatura sapiencial en tiempos de Alfonso el Sabio", en la página http://www.saavedrafajardo.org/archivos/NOTAS/RES0118.pdf.
} 
del lenguaje, por la necesidad que de él tiene todo hombre, ya que es el instrumento y el paso hacia toda sabiduría y virtud, además de explicar cómo se obtiene todo saber.

Sin embargo, algunos sabios despreciaban el saber de los oradores, lingüistas y gramáticos, y la emprendieron contra los que se ocupaban de él, entre ellos Epicuro y Pitágoras ${ }^{26}$. Afirmaban que no había necesidad de tal saber para cualquier cosa propia de la sabiduría, puesto que los gramáticos sólo eran maestros de los niños, los poetas eran autores de mentiras y embustes y los oradores eran autores de intrigas, venalidad e hipocresía. Cuando esto llegó a oídos de Aristóteles, se apoderó de él una justa cólera contra ellos, defendió a los gramáticos, oradores y poetas y argumentó contra ellos diciendo: "Es imprescindible [180] para la sabiduría el conocimiento que ellos poseen, puesto que la palabra es un instrumento para su saber". Y añadió: "La superioridad del hombre sobre los animales se debe a la palabra; el más digno de ellos en cuanto a la humanidad es el más elocuente en su expresión, el que mejor comunica en palabras la esencia de su alma, el que mejor dispone las palabras en su lugar y el que más hermosamente las elige para compendiar su discurso y hacerlo ameno. Puesto que la sabiduría es la más noble de las cosas, debe ser expresada por medio del lenguaje más exacto, por la lengua más elocuente y por la expresión más concisa, alejada del error y del desliz, de las palabras horribles, del torpe tartamudeo y de la dificultad de expresión. Todo esto destruye la luz de la sabiduría, interrumpe la expresión, abandona la precisión, confunde al oyente, corrompe la significación y causa oscuridad".

Cuando [Aristóteles] finalizó el conocimiento de los poetas, de los gramáticos y de los oradores, habiendo profundizado en él, se propuso estudiar ética, política, física, matemáticas y teología. Entonces prestó oídos a Platón, llegando a ser alumno y discípulo suyo. Tenía en ese momento diecisiete años. Esto ocurrió en un lugar llamado Academia, en Atenas, tierra de sabios. Permaneció aprendiendo la filosofía de Platón veinte años. Aprendía el saber del mismo Platón, oyéndolo de su propia boca, pues no lo confió a la enseñanza de Jenócrates, como solía hacer con otros discípulos, debido a la sublimidad que descubrió en su alma. Una vez Platón se sentó y fue requerido para que empezara a hablar. Entonces dijo: "[Esperaré] hasta que alguien comparezca". Cuando llegó Aristóteles, dijo: "Ahora ya hablaremos, puesto que ha comparecido ese alguien". Otras veces decía: "Hasta que comparezca la Inteligencia ( $a l$ - 'aql)". Cuando llegaba Aristóteles, decía: "Hablaremos ya, pues la Inteligencia ha comparecido". Cuando Platón se ausentó a Sicilia por segunda vez, nombró como representante suyo a Aristóteles en la sede de la enseñanza, el lugar llamado Academia.

Cuando Platón murió, Aristóteles marchó a un lugar en Atenas llamado Liceo. [181] Aquí tomó una casa para enseñar filosofía, que pasó a designar a los filósofos

\footnotetext{
${ }^{26}$ A. Badawi sugiere en nota 8 leer Pródicos o Protágoras en lugar de Epicuro, nombres cuyas transliteraciones en árabe son muy parecidas a la de Epicuro.
} 
que allí paseaban, pues era opinión de Platón que el ejercicio del cuerpo, por medio de un moderado esfuerzo, para anular las cosas inútiles que hay en él, es como el ejercicio del alma por medio de la sabiduría; es necesario reunir ambos, esfuerzo [corporal] y sabiduría, para ejercitar alma y cuerpo. Habiendo ordenado esto a Aristóteles y a Jenócrates, ambos enseñaban la filosofía a sus discípulos mientras paseaban; por eso, ellos y quienes los seguían fueron apodados "peripatéticos".

Jenócrates permaneció en la Academia para enseñar el saber de Platón. En cambio, la enseñanza de toda la filosofía de Aristóteles, además de la composición de libros de lógica y de otras partes de la filosofía, tuvo lugar en el sitio a donde se trasladó, llamado Liceo. Y aquí guardó los libros. Su filosofía y sus libros fueron llamados en aquella época "el saber que responde a la verdad y que le presta oídos".

Después que hubo muerto Platón, Aristóteles marchó junto al esclavo Hermias a Atarnea. Cuando este esclavo murió, volvió a Atenas. Entonces le escribió Filipo. Fue a Macedonia, junto a él y se quedó allí, enseñando la filosofía hasta que Alejandro marchó a tierras de Asia. Entonces Aristóteles nombró como sucesor suyo en Macedonia a Calístenes, mientras él volvía a Atenas; permaneció en el Liceo durante diez años dedicado a la enseñanza.

Se levantó contra él un hombre, el sacerdote llamado Eurimedonte, quien lo acusó, impugnando su doctrina, de no prosternarse ante las imágenes que eran adoradas en aquella época y de no honrarlas, a causa de la envidia que le tenía y de un viejo odio que sentía en su interior hacia él. Cuando se dio cuenta de esto, se marchó [182] de Atenas a su país, la Calcídica, temiendo que hicieran con él lo que habían hecho con el moderado Sócrates, a quien ellos habían matado por medio del veneno. Llegó a este lugar que hemos citado para estudiar la marea del canal de Euripos, que está por Eubea, y su corriente, y para escribir un libro sobre eso. Pero aquí le llegó la muerte. Murió y fue enterrado en esta tierra. Contaba a la sazón sesenta y ocho años.

Cuando Filipo murió y su hijo Alejandro reinó después, marchó de Macedonia para guerrear contra los pueblos y conquistó las tierras de Asia, Aristóteles se retiró y renunció a aquel vínculo que mantenía con los asuntos del rey. Entonces preparó la sede de la enseñanza, que ya hemos citado, y comenzó a preocuparse por el bienestar de la gente, a socorrer a los débiles, a casar a las viudas, a mantener a los huérfanos, a ayudar a quienes solicitaban saber y educación, quienes quiera que fuesen y cualquier que fuese la clase de educación y de saber que buscasen, socorriéndoles para ello, a dotar a los menesterosos y a prescribir lo útil para las ciudades. Restauró los edificios de la ciudad de Estagira y fue él quien estableció las leyes para los habitantes de Estagira. Excelsa fue su estima entre los hombres y grandes honores y elevado rango obtuvo entre los reyes.

Cuando murió, los habitantes de Estagira trasladaron sus restos (rimma) después de haberse descompuesto; tomaron sus huesos ${ }^{27}$ y lo colocaron en una vasija de

\footnotetext{
${ }^{27}$ Esta frase no aparece en el texto, sino en otro manuscrito, citado en nota al margen.
} 
cobre y lo sepultaron en un lugar llamado Aristoteleion, lugar de reunión para ellos, donde se congregaban para deliberar acerca de asuntos importantes y de aquello que les afligía; se apoyaban sobre su tumba y se tranquilizaban sobre sus huesos. Cuando les resultaba difícil alguna parte [183] de la ciencia o de la filosofía, iban a ese lugar, se sentaban allí y deliberaban entre sí hasta que lograban resolver lo que les era confuso y se les mostraba correcto aquello por lo que discutían. Creían que ir al lugar donde estaban los huesos de Aristóteles avivaba sus inteligencias, hacía correcta su reflexión y sutil su discernimiento. También iban a honrarle después de su muerte, a afligirse por su ausencia y a apenarse por causa de haberlo perdido y por estar privados de las fuentes de la filosofía.

Tuvo muchos discípulos, entre ellos reyes, hijos de reyes y otros, entre los que están Teofrasto, Eudemo, el rey Alejandro, Hermias, Escolos (Asjûlûs) y otros hombres excelentes, célebres por la ciencia, sobresalientes en ciencia y filosofía y conocidos por su noble linaje. Teofrasto, hijo de su tía materna, ocupó su lugar después de él, sentándose sobre su cátedra y heredando su mismo rango, para enseñar la filosofía; con él había dos hombres que le ayudaban y lo asistían, llamados Herminos ( $A r$ mînûs) uno y Escolos (Asjûlûs) el otro. Compusieron libros sobre lógica y filosofía.

Dejó como descendencia un hijo pequeño, llamado Nicómaco, y una hija pequeña. También dejó muchos bienes, esclavos y muchas esclavas, así como otras cosas. Designó como albacea de su testamento a Antípatro y a un grupo de amigos para que lo ayudaran. Eligió a Teofrasto para que cooperara con ellos en el testamento y en la administración, si es que le resultaba fácil.

Escribió muchos libros, unos cien. Dicen que, además de estos cien, compuso otros libros, entre los que hay veinte que conocemos hoy, pues disponemos de ellos: [184] son ocho libros de lógica ${ }^{28}$, un libro de ética, un libro sobre el gobierno de las ciudades, un gran libro sobre metafísica, conocido por Teología, que quiere decir "discurso divino", y un libro sobre mecánica. También hay entre ellos epístolas y escritos varios, algunos conocidos por los nombres a los que están dirigidos, pero no disponemos de ellos; son muchos.

Platón lo desaprobó por la filosofía que exponía y por los libros que escribía; él le replicó excusándose: "Los hijos y los herederos de la filosofía no deben profanarla; sus enemigos y los que renuncian a ella no la alcanzan por ignorar lo que hay en ella, por desdeñarla y por su aversión a ella, a causa de la dificultad que tiene para ellos. He fortalecido esta filosofía al divulgarla, de una manera inexpugnable e inaccesible, para que no la acosen los necios ni la alcancen los ignorantes ni la obtengan los perversos. La he ordenado en tal disposición que es insignificante para los filósofos e inaccesible para los falsarios y embusteros" ${ }^{\prime 29}$.

\footnotetext{
${ }^{28}$ En el texto no se hace referencia a los ocho libros de Física, que sí figuran en la traducción de Düring.

${ }^{29}$ Esta última frase se encuentra en la obra de al-Fârâbî titulada Concordia entre Platón y Aristóteles, trad. cast. M. Alonso, Pensamiento 25 (1969) p. 34.
} 
Aristóteles era de piel blanca y un poco calvo, de hermosa figura, corpulento, de ojos pequeños, de poblada barba, de ojos azul intenso, de nariz aguileña, de boca pequeña y ancho de pecho. Era rápido en su marcha cuando estaba solo, pero era lento cuando sus amigos iban con él. Siempre estaba estudiando libros. Nunca decía cosas desagradables. Era comedido en cada palabra y permanecía silencioso durante un tiempo antes de responder. Era exiguo en sus respuestas. En algunos momentos del día se trasladaba a los campos sin agua y a los ríos. Le gustaba oír melodías y reunirse con matemáticos y dialécticos. Era equitativo cuando disputaba; reconocía la postura correcta y la equivocada. Era equilibrado en el vestir, en el comer, en el beber, en el sexo y en las emociones. Poseía instrumentos para medir los astros y las horas.

Murió cuando contaba sesenta y ocho años de edad.

\section{La vida de al-Qiftî}

Ŷamâl al-Dîn Abû 1- Hasan 'Alî b. Yûsuf al-Qiftî̉ ${ }^{30}$, estudioso egipcio de finales del siglo XII y comienzos del XIII, compuso varias obras, de las que se ha conservado su Kitâb Ijbâr al- 'ulamâ' bi-ajbar al-hukamâ', más conocida por Ta'rîj alhukamâ' '(Historia de los sabios) ${ }^{31}$, donde transmite más de cuatrocientas biografías de médicos, filósofos y astrónomos, entre las que se cuenta otra vida de Aristóteles, que ocupa las páginas 27-34, aunque en ella incluye narraciones que no tienen nada que ver con la propia biografía del filósofo griego.

\section{[27] Aristóteles}

Hijo del pitagórico Nicómaco de Gerasa ${ }^{32}$. La explicación del nombre de Aristóteles es "el de virtud perfecta".

Aristóteles fue discípulo de Platón. Ocupó el primer puesto durante algún tiempo en las dos ocasiones en que tuvo que ponerse al frente de sus seguidores. Estuvo junto a Platón para aprender de él [28] durante veinte años. Platón lo prefería al resto de sus discípulos y lo llamó "la Inteligencia".

La filosofía griega llegó a su término con Aristóteles, pues él fue el último de los sabios y el señor (sayyid) de los hombres de ciencia griegos. Fue el primero que separó el arte de la demostración de las restantes artes lógicas, pues le dio forma por medio de las tres figuras y lo estableció como el instrumento de las ciencias teóricas, hasta el punto de que recibió el nombre de arte de la Lógica.

\footnotetext{
${ }^{30}$ Cf. A. Dietrich: "Ibn al-Ķiftı̂”, en Encyclopaedia of Islam, vol. III, p. 840.

${ }^{31}$ Ed. Julius Lippert, Leipzig, Dieterich'sche Verlagsbuchhandlung, 1903.

${ }^{32}$ Evidente confusión con el matemático neopitagórico Nicómaco de Gerasa, de finales del siglo I y comienzos del II, autor de la Introducción a la aritmética, texto traducido al árabe por Tâbit b. Qurra (m. 901).
} 
Tiene libros excelentes, universales y particulares, acerca de todas las ciencias filosóficas. Los libros particulares son sus epístolas, en las que estudia una sola idea. De sus libros universales, unos son mnemónicos, por cuya lectura se recuerda el conocimiento de lo ya adquirido; son setenta libros, que compuso para Eufaros ${ }^{33}$; otros son escritos propedéuticos, que estudian tres cosas: la filosofía, sus aplicaciones y el instrumento empleado en filosofía y otras ciencias. De los libros que versan sobre filosofía, unos tratan de las matemáticas, otros de la física y otros de la teología (al-'ulûm al-ilâhiyya). Los libros que tratan de las matemáticas son Sobre la óptica, Sobre las líneas y Sobre la mecánica. De los libros que versan sobre la física, unos son aquellos en que se estudia lo que es propio de cada una de las cosas naturales y otros son aquellos en los que se estudia lo que es común a todas las cosas naturales. El libro en el que estudia lo que es común a todas las cosas naturales es el llamado Física; este libro da a conocer el número de los principios de todas las cosas, lo que es como los principios, las cosas que siguen a los principios y las cosas que se asemejan a las que siguen a los principios. Los principios son la materia y la forma; lo que es como los principios no es principio en realidad, sino casi, como la privación. Lo que sigue a los principios es el tiempo y el lugar; lo que se asemeja a lo que sigue a los principios es el vacío y el infinito. Según este orden están dispuestos todos sus libros para quien se aplica a ellos. Como no es el momento de citarlos aquí, dejo de mentar su orden, puesto que es [29] intención nuestra componer otro escrito que trate de ellos y cuya lectura impida la ignorancia de los contemporáneos y la estupidez de los compañeros en la investigación. ¡Que Dios nos asista!

Aristóteles fue maestro de Alejandro, hijo de Filipo, rey de Macedonia. Con sus normas de conducta, Alejandro actuó para gobernar a sus súbditos y para regir su reino, subyugó el politeísmo en Grecia, se manifestó el bien y se expandió la justicia. Aristóteles le dirigió muchas epístolas, conocidas y recopiladas.

Por causa de Aristóteles, la filosofía y otras ciencias antiguas se desarrollaron en los países islámicos. La explicación de cómo sucedió esto la cuenta Muhammad b. Ishâq al-Nadîm en su libro... ${ }^{34}$.

[31] Muhammad b. Ishâq al-Nadîm cita en su libro a Aristóteles y dice: Su significado es el de "amante de la sabiduría". También se ha dicho: "el excelente", "el perfecto". También se ha dicho: "el mejor", "el excelente". [32] Aristóteles fue hijo de Nicómaco, hijo de Macaón, de los hijos de Esculapio, el que inventó la medicina para los griegos.

\footnotetext{
${ }^{33}$ Así en el texto árabe. Según Düring: Aristotle in the biographical Tradition, p. 238, se trataría de Eukairos, mencionado por Elias.

${ }^{34}$ A partir de aquí al-Qiftî olvida la biografía de Aristóteles y expone cómo se difundió la filosofía en el mundo árabe y se enviaron embajadas a Bizancio para traer los libros de Aristóteles a Bagdad, según el relato de al-Nadîm y de otro autor distinto. Al final de la página 31 vuelve a la biografía de Aristóteles, tomándola literalmente de al-Nadîm, con muy escasa variaciones.
} 
Ptolomeo el Extranjero contó lo siguiente: El nombre de su madre era Festias y descendía de Esculapio. Era de una ciudad griega que se llama Estagira. Su padre Nicómaco ejercía la medicina para Filipo, el padre de Alejandro. Fue uno de los discípulos de Platón. Ptolomeo continuó diciendo: Se puso bajo la dirección de Platón por inspiración de Dios Altísimo en el templo de Pition. También dijo: Permaneció aprendiendo durante veinte años y, cuando Platón se ausentó a Sicilia, Aristóteles le sucedió en la sede de la enseñanza.

Se ha dicho que estudió la filosofía después de haber cumplido los treinta años de edad. Fue el más elocuente de los griegos y de sus escritores, el más ilustre de sus sabios después de Platón y el que alcanzó un grado sublime en filosofía y un lugar grandioso entre los reyes. Por consejo suyo, Alejandro administraba sus asuntos.

Cuando Alejandro se dirigió a guerrear contra las naciones, Aristóteles se retiró y se hizo asceta. Se dirigió entonces a unos edificios que había erigido como lugar de enseñanza: es el lugar que está en relación con los filósofos peripatéticos. Se dedicó entonces a ocuparse de las necesidades de los hombres, a proteger a los débiles y a restaurar los edificios de la ciudad de Estagira y construyó fuentes en ella.

Aristóteles murió al comienzo del reinado de Ptolomeo Lagos. Teofrasto, hijo de su hermana, le sucedió en la enseñanza.

Cuando le llegó la hora de su muerte, [Aristóteles] dijo:

"He designado albacea mío a perpetuidad, para todo lo que he dejado, a Antípatro. Hasta que Nicanor llegue a ser el más antiguo, que Aristómenes, Timarco, Hiparco y Dioteles se ocupen de supervisar lo que haya que realizar y se cuiden de aquellos asuntos de mi familia que así lo requieran, de mi sierva Herpilis, de los otros siervos y esclavos míos y de lo que he dejado. Si Teofrasto puede permanecer con ellos y si le es fácil hacerlo, que se encargue también de ello.

Hasta que mi hija alcance la madurez, Nicanor se hará cargo de sus asuntos. Si muriera antes de casarse o después de casarse pero sin tener ningún hijo, entonces sus asuntos retornarán a Nicanor, así como los asuntos de mi hijo Nicómaco. [33] El consejo que le doy en esto es que proceda en la administración de lo que hace según crea conveniente y según le convenga.

Si Nicanor muriese antes de casarse mi hija o después de casarse sin tener ningún hijo, y si Nicanor deja en testamento lo que yo he dejado, que sea válido y efectivo. Si Nicanor muere sin hacer testamento y si le es fácil a Teofrasto, me gustaría que ocupase su lugar en el asunto de mi hijo y en los otros asuntos que he dejado; si Teofrasto no quiere ocuparse de ello, entonces que los albaceas que he nombrado recurran a Antípatro y le consulten lo que han de hacer sobre lo que he dejado y que ejecuten los asuntos según lo que decidan de acuerdo con él.

Que Nicanor y los albaceas me tengan presente en Herpilis, pues ella merece eso de mí, por el cuidado que según he visto puso en servirme y por su desvelo en corresponder a mi alegría. Que se ocupen de todo lo que ella necesite. Si quiere casarse, que no lo haga si no es con un hombre virtuoso. Que se le entreguen, además de lo 
que ya tiene, un talento de plata, que es igual a ciento veinticinco libras, y tres esclavas entre las que ella prefiera, además de la esclava y del esclavo que ya posee. Si quiere permanecer en Calcis, que habite en mi casa, en la hospedería, que está junto al jardín. Si, por el contrario, prefiere residir en la ciudad de Estagira, que viva en la casa de mis padres. Sea cual fuere la casa que elija, que los albaceas tomen para ella todo lo que diga necesitar.

En cuanto a mi familia y a mi hijo, no tengo necesidad de dejarles testamento para su protección y para el cuidado de sus asuntos. Que Nicanor cuide del joven esclavo Myrmex hasta que regrese a su país con todos sus bienes, de la manera que desee. Que mi esclava Ambracis sea emancipada y, si después de manumitida quiere permanecer al servicio de mi hija hasta que se case, que se le entreguen quinientos dracmas y su joven esclava. Que a Tales [34] se le entreguen la joven que recientemente hemos adquirido, uno de nuestros jóvenes esclavos y mil dracmas. Que a Simos se le entregue el precio de un esclavo que pueda comprar para sí, distinto del joven esclavo cuyo precio ya se le había entregado y que se le dé además lo que acuerden los albaceas.

Cuando mi hija se case, que sean emancipados mis jóvenes esclavos Tacón, Filón y Olimpio ${ }^{35}$. Que el hijo de Olimpio no sea vendido ni ningún otro de mis esclavos que han estado a mi servicio, sino que permanezcan sirviendo hasta que alcancen la madurez de los hombres; cuando lleguen a la edad adulta, que sean emancipados; lo que se les haya de dar, que se haga según lo que merezcan".

Dijo Ishâq b. Hunayn que Aristóteles vivió sesenta y siete años. Dios es el más sabio.

\section{La vida de Ibn Abî Usaybi‘a}

Muwaffaq al-Dîn Abû l-‘Abbâs Ibn Abî Usaybi‘ ${ }^{36}$, médico y bibliógrafo nacido en Damasco en 1194, escribió varias obras de medicina, hoy perdidas. Se conserva de él el libro 'Uyûn al-anbâ' fì tabaqât al-atibbâ (Fuentes de información sobre las clases de los médicos) $)^{37}$, colección de trescientas ochenta biografías de gran importancia para la historia de la ciencia. Entre ellas se encuentra la de Aristóteles, en la que se sirve de las anteriores vidas, copiando incluso amplios textos de ellas. Es la siguiente:

\footnotetext{
${ }^{35}$ En el testamento que transmite al-Nadîm aparece el nombre de Herpilis. Aquí, el de Olimpio.

${ }^{36}$ Cf. J. Vernet: "Ibn Abî Usaybi'a”, en Encyclopaedia of Islam, vol. III, pp. 693-694.

${ }^{37}$ Kitâb 'Uyûn al-anbâ' fî tabaqât al-atibbâ', ed. A. Müller, 2 vols. El Cairo, 1299/1899. La vida de Aristóteles en el volumen I, pp. 54-69. Sigo esta edición. Hay nueva edición por Nizâr Ridâ, Beirut, 1965; vida de Aristóteles en pp. 86-105.
} 


\section{[54] Aristóteles}

Aristóteles fue hijo de Nicómaco de Gerasa, el pitagórico. Nicómaco quiere decir "vencedor del adversario" y Aristóteles significa "el de virtud perfecta". Esto dice Abû -1- Hasan'Alî b. al- Husayn b. 'Alî al-Mas "udîn'. Nicómaco fue de la secta pitagórica y escribió un célebre libro sobre Aristóteles.

Sulaymân b. Hasan, conocido por Ibn Ŷulŷul, dice en su libro acerca de Aristóteles: Fue filósofo de Grecia (al-Rûm), sabio, hombre dotado de mente crítica, versado, orador y médico. Dice que fue único en la medicina y que hizo triunfar la filosofía ${ }^{39}$.

Dice Ptolomeo en su libro a Gallus sobre la vida de Aristóteles, su historia, su testamento y el catálogo de sus libros, que Aristóteles era originario de la ciudad llamada Estagira, en el país conocido por Calcídica, que depende de las tierras de Tracia, cerca de Olinto y Metone. El nombre de su madre era Festias. Dice que Nicómaco, el padre de Aristóteles, fue médico de Amintas, padre de Filipo. Este Filipo fue padre del rey Alejandro. El linaje de Nicómaco remonta a Esculapio. Este Esculapio fue padre de Macaón y Macaón fue padre de Esculapio. En cuanto al linaje de su madre, Festias, su origen también remonta a Esculapio. Dice que cuando murió su padre Nicómaco, Proxeno, encargado de su padre, lo entregó a Platón, siendo joven aún.

Alguien ha dicho que la entrega de Aristóteles a Platón tuvo lugar por una revelación de Dios Altísimo en el templo de Pition. También alguien ha dicho que eso ocurrió por la amistad que había entre Proxeno y Platón.

Se ha dicho que permaneció aprendiendo con Platón durante veinte años y que, cuando Platón volvió por segunda vez a Sicilia, Aristóteles fue su sucesor en la escuela llamada Academia. Se dice también que cuando Platón regresó de Sicilia, Aristóteles se trasladó al Liceo y estableció aquí la escuela que fue llamada la de los filósofos peripatéticos.

Cuando Platón murió, fue a Hermias el esclavo, gobernante de Atarnea. Cuando este esclavo murió, regresó a Atenas, que es conocida como la ciudad de los sabios. Entonces Filipo se dirigió a él. Fue a Macedonia, donde permaneció enseñando hasta que Alejandro marchó a Asia. Nombró como sucesor suyo en Macedonia a Calístenes y él regresó a Atenas, residiendo en el Liceo diez años.

Ocurrió entonces que un hombre, sacerdote de los llamados hierofantes, de nombre Eurimedonte, quiso intrigar contra Aristóteles, acusándolo de impiedad y diciendo que no honraba a las imágenes que eran adoradas en aquella época. Esto lo hizo por causa del odio que sentía interiormente contra Aristóteles, quien ha narrado este

\footnotetext{
${ }^{38}$ Abû 1- Hasan al-Mas'ûdî (m. 957) nacido en Bagdad, historiador y geógrafo, contribuyó con su obra a fundar sobre bases sólidas la historia en el Islam. Se conservan de él dos títulos: Murûŷal-dahab (Las praderas de oro) y Kitâb al-tanbîh (Libro de la advertencia).

${ }^{39}$ Véase J. A. García-Junceda - R. Ramón Guerrero: "La vida de Aristóteles de Ibn Ŷulŷul”. Este pasaje no se encuentra en la traducción de I. Düring.
} 
suceso en su libro a Antípatro. Cuando Aristóteles supo esto, partió de Atenas para su tierra Calcídica, porque temía que los atenienses hicieran con él algo semejante a lo que habían hecho con Sócrates, el maestro de Platón, a quien mataron. Marchó sin que nadie se atreviera a hacerle algo, después de recibir el escrito del sacerdote y su acusación y de darla por falso. Lo que se cuenta de Aristóteles, a saber, que se excusó de la acusación del hierofante, no es verdad; al contrario, ha de ser establecido como una maledicencia. Cuando Aristóteles llegó a su país, permaneció [55] aquí el resto de su vida, hasta que murió con sesenta y ocho años.

Dice [Ptolomeo]: Lo que hemos mencionado sobre sus circunstancias muestra la falsedad de quienes afirman que sólo estudió la filosofía después de haber alcanzado los treinta años de edad y que hasta ese momento sólo se había ocupado de gobernar las ciudades, siendo su interés reformar los asuntos de las ciudades.

Se dice que los habitantes de Estagira trasladaron su cuerpo hasta allí desde el lugar en que había muerto y lo pusieron en el lugar llamado Aristoteleion, donde establecieron un lugar de encuentro para deliberar acerca de asuntos importantes y de aquello que les afligía en ese sitio.

Aristóteles fue quien estableció leyes para los habitantes de Estagira. Tuvo una gran influencia entre las gentes. Hay pruebas claras de esto por los honores que los reyes de su época le dispensaron. En cuanto al deseo que tuvo de hacer favores y de preocuparse por las buenas obras para los hombres, queda manifiesto por sus epístolas y sus libros, pues el que los estudia puede saber sobre ello y sobre sus numerosas intervenciones en asuntos entre los reyes y los hombres de su época, arreglando sus asuntos y siéndoles útil por su mediación. Por los numerosos beneficios y buenas acciones que concluyó en este dominio, los atenienses llegaron a reunirse y se comprometieron a grabar una inscripción en una columna de piedra que situaron en la ciudad elevada que hay sobre la ciudad, llamada Acrópolis. El escrito en esta columna hacía mención del hecho de que Aristóteles, hijo de Nicómaco, estagirita, era merecedor de ello por los favores que había hecho, por sus muchos bienes y beneficios y por su dedicación a los atenienses, al haberse ocupado ante el rey Filipo por mejorar sus asuntos y lograr buenas obras para ellos; [mencionaba también] que los atenienses tenían claro el bien que había obtenido para ellos, le reconocían su superioridad y su autoridad y se obligaban a guardarle memoria y custodia.

Entre las autoridades hubo quienes le juzgaron indigno de eso y ellos siguieron sus pasos realizando para sí todos los negocios y asuntos que buscaban. Después de que los atenienses hubieron acordado elevar esta inscripción, hubo un hombre, llamado Himereus, que se apartó de este acuerdo. Manifestó una opinión diferente acerca del asunto de Aristóteles y saltó sobre la columna en la que los atenienses habían acordado grabar una inscripción de alabanza y que habían erigido en el lugar llamado Acrópolis, la tiró de su sitio arañándola. Después de hacer esto, Antínoo ${ }^{40}$

\footnotetext{
${ }^{40}$ Según Düring, p. 216, n.1, hay que leer Antípatro,
} 
lo mató. A continuación otro ateniense de nombre Estefanos, con la ayuda de otros, erigió una columna de piedra y en ella grabaron con un cincel alabanzas a Aristóteles, semejantes a las que había en la primera columna y registraron también la mención de Himereus, el que había derribado la columna, y lo que había hecho; obligaron a maldecirlo y a liberarse de él.

Cuando murió Filipo y reinó después de él Alejandro y éste marchó de su país para combatir contra los pueblos y tomar posesión de las tierras de Asia, Aristóteles se retiró y renunció al vínculo que mantenía con los asuntos del rey y a dejar de inmiscuirse en ellos. Llegó a Atenas y dispuso el lugar de la enseñanza que hemos mencionado anteriormente, que fue denominado el lugar de los filósofos peripatéticos. Comenzó entonces a preocuparse por el bienestar de los hombres, a socorrer a los débiles y a los pobres, a casar a las viudas, a mantener a los huérfanos y procurarles su educación, a ayudar a quienes solicitaban enseñanza y educación, quienes quiera que fuesen y cualquiera que fuese la clase de saber y educación que buscasen, socorriéndoles para ello y estimulándolos a ello; [comenzó] a dotar a los menesterosos y a prescribir lo útil para las ciudades. Restauró los edificios de la ciudad de Estagira.

No dejó de ser afable y humilde hasta el límite, era correcto en su trato para el pequeño y para el grande, el poderoso y el débil y su preocupación hacia sus amigos es indescriptible. [56] Muestra esto lo que han escrito los biógrafos y la unanimidad muestran en lo que escriben sobre la historia y la vida de Aristóteles.

El emir al-Mubaššir b. Fâtik dice en su libro Mujtâr al-hikam ${ }^{41}$ que cuando Aristóteles alcanzó los ocho años de edad fue llevado por su padre a Atenas, conocida por la tierra de sabios. Se instaló en el liceo de allí, donde su padre lo reunió con los poetas, oradores y gramáticos, permaneciendo aquí durante nueve años aprendiendo de ellos. El nombre de este saber, ciencia del lenguaje, era para ellos el de "la circundante", por la necesidad que tiene de él todo hombre, ya que es el instrumento y el paso hacia toda sabiduría y virtud, además de explicar cómo se obtiene todo saber.

Sin embargo, algunos sabios despreciaban el saber de oradores, lingüistas y gramáticos y la emprendieron contra los que se ocupaban de él, entre ellos Epicuro y Pitágoras. Éstos afirmaban que no había necesidad de tal saber para cualquier cosa propia de la sabiduría, porque los gramáticos sólo son maestros de los niños, los poetas son autores de embustes y mentiras y los oradores son autores de intrigas, venalidad e hipocresía. Cuando esto llegó a oídos de Aristóteles, se apoderó de él una justa cólera contra ellos, defendió a los gramáticos, poetas y oradores y argumentó contra ellos diciendo: "Es imprescindible para la sabiduría el saber que ellos poseen, puesto que la palabra es un instrumento para su saber". Añadió: "La superioridad del hombre sobre los animales se debe a la palabra; el más digno de ellos en cuanto a la humanidad es el más elocuente en su expresión, el que mejor comunica en palabras

\footnotetext{
${ }^{41}$ Véase la biografía de al-Mubaššir antes transcrita.
} 
la esencia de su alma, el que mejor dispone las palabras en su lugar y el que más hermosamente las elige para compendiar su discurso y hacerlo ameno. Puesto que la sabiduría es la más noble de las cosas, debe ser expresada por medio del lenguaje más exacto, por la lengua más elocuente y por la más concisa expresión, alejada del error y del desliz, de las palabras horribles, del torpe tartamudeo y de la dificultad de expresión. Todo esto destruye la luz de la sabiduría, interrumpe la expresión, abandona la precisión, confunde al oyente, corrompe la significación y causa oscuridad".

Cuando Aristóteles finalizó el conocimiento de poetas, gramáticos y oradores, habiendo profundizado en ese conocimiento, se propuso estudiar ética, política, física, matemáticas y teología. Entonces prestó oídos a Platón, llegando a ser alumno y discípulo suyo. Tenía en ese momento diecisiete años.

Dice al-Mubaššir b. Fâtik: Una vez Platón se sentó y fue requerido para que empezara a hablar. Entonces dijo: "Hasta que alguien comparezca". Cuando llegó Aristóteles, dijo: "Hablaremos ya, pues ha comparecido ese alguien". Otras veces decía: "Hasta que comparezca la Inteligencia". Cuando llegaba Aristóteles, decía: "Hablaremos ya, pues la Inteligencia ha comparecido".

Dice también que cuando Aristóteles murió los habitantes de Estagira trasladaron sus restos después de haberse descompuesto; tomaron sus huesos y lo colocaron en una vasija de cobre y los sepultaron en el lugar llamado Aristotelelion, que convirtieron en lugar de encuentro para ellos, donde se reunían para deliberar acerca de asuntos importantes y de lo que les afligía; se apoyaban sobre su tumba y se tranquilizaban sobre sus huesos. Cuando les resultaba difícil alguna parte de la ciencia o de la filosofía, iban a ese lugar, se sentaban allí y deliberaban entre sí hasta que lograban resolver lo que les era confuso y se les mostraba correcto aquello por lo que discutían. Creían que ir al lugar donde estaban los huesos de Aristóteles avivaba sus inteligencias, hacía correcta su reflexión y sutil su discernimiento. También iban a honrarle después de su muerte, a afligirse por su ausencia y a apenarse por causa de haberlo perdido y por estar privados de las fuentes de la filosofía.

Dice al-Mas'ûdî̀ ${ }^{42}$ en su Kitâb al-masâlik wa-l-mamâlik que en una gran ciudad de la isla de Sicilia, llamada Lazam $^{43}$, hay una gran mezquita aljama, que antes había sido una iglesia cristiana, donde hubo en otra época un amplio templo. Dice: $\mathrm{He}$ oído afirmar a algunos lógicos que un sabio griego, Aristóteles, estaba suspendido de un madero en este templo, que los musulmanes adoptaron como mezquita. Dicen que los cristianos honraban el poder de esta imagen, pues buscaban su curación por mediación de ella, y que los griegos dieron testimonio (šâhadat) [57] de su grandeza y de su magnitud. Dicen que la causa por la que estaba suspendido entre el cielo y la tierra era que la gente acudía para buscar la curación y pedir la lluvia y otros asuntos

\footnotetext{
${ }^{42}$ Este libro de al-Mas'ûdî del que cita Ibn Abì Usaybi‘a, el Kitâb al-masâlik wa-l-mamâlik (Libro de las rutas y de los reinos), no se conserva.

${ }^{43}$ Düring, p. 217: Jalzam (Messana), hoy Mesina.
} 
importantes que son necesarios para temer a Dios Altísimo y acercarse a Él en los momentos de turbación y de ruina, y para poner de acuerdo a unos con otros. Dice alMas' ûdî: He visto aquí un madero grande en donde se sospecha que estaba la tumba.

Dice al-Mubaššir b. Fâtik: Aristóteles tuvo muchos discípulos: reyes, hijos de reyes y otros, entre los que están Teofrasto, Eudemo, el rey Alejandro, Herminos, Escolos y otros hombres excelentes, célebres por la ciencia, sobresalientes en filosofía y conocidos por su noble linaje. Teofrasto, hijo de su tía materna (= del que era tío materno), ocupó su lugar después de él, sentándose en su cátedra y heredando su mismo rango para enseñar la filosofía; con él había dos hombres que le ayudaban y le asistían, llamados uno Herminos y Escolos el otro. Compusieron libros sobre lógica y filosofía.

Dejó como descendencia un hijo pequeño, llamado Nicómaco, y una hija pequeña. También dejó muchos bienes, esclavos y muchas siervas, así como otras muchas cosas.

Dice que Aristóteles era de piel blanca y un poco calvo, de figura hermosa, corpulento, de ojos pequeños, de barba espesa ( $k a t t$ ), de ojos azul intenso, de nariz aguileña, de boca pequeña, ancho de pecho. Era rápido en su marcha cuando estaba solo, pero era lento cuando sus amigos iban con él. Siempre estaba estudiando libros. Nunca decía cosas desagradables. Era comedido en cada palabra y permanecía silencioso durante un rato antes de responder. Era exiguo en sus respuestas. En algunos momentos del día se trasladaba a los campos sin agua y a los ríos. Le gustaba oír melodías y reunirse con matemáticos y dialécticos. Era equitativo cuando disputaba; reconocía la postura correcta y la equivocada. Era equilibrado en el vestir, en el comer, en el sexo y en las emociones. Poseía instrumentos para medir los astros y las horas.

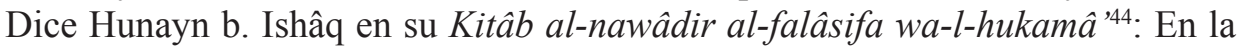
piedra engastada en el sello de Aristóteles está grabado lo siguiente: "El que niega lo que no conoce es más sabio que el que confiesa lo que conoce".

Dice el maestro Abû Sulaymân Muhammad b. Tâhir b. Bahrâm al-Mantiqî en sus Ta âlî $q$ (Notas) $)^{45}$ que Teofrasto ${ }^{46}$ fue albacea de Aristóteles y que Aristóteles vivió sesenta y un años. De Platón dice que vivió mucho.

Dice Ibn al-Nadîm al-Bagdâdî, el escritor, en su Kitâb al-Fihrist que Aristóteles murió cuando tenía sesenta y seis años.

\footnotetext{
${ }^{44}$ Se trata de la obra original de la que luego surgió la citada antes en nota 6, Âdab al-falâsifa, traducida al castellano en el siglo XIII como Libro de los buenos proverbios.

${ }^{45}$ Se trata de Abû Sulayman al-Siŷistâni citado anteriormente como autor del Siwân al-hikma (El armario de la sabiduría). De estas Notas de las que habla Ibn Abî Usaybi‘a no hay noticias, cf. S. M. Stern: "Abû Sulaymân al-Mantiqî”, en Encyclopaedia of Islam, vol. I, Edited by an Editorial Committee Consisting of H. A. R. Gibb, J. H. Kramers, E. Lévi-Provençal, J. Schacht, Leiden, J. Brill, 1986, pp. 151-152.

${ }^{46}$ En el texto se lee claramente "Teofrasto", no "Sarakostas", como dice Düring, p. 218.
} 
Del puño y letra de Ishâq [b. Hunayn] y según sus palabras: Aristóteles vivió sesenta y siete años.

Dice el cadí Abû l-Qâsim Sâ‘id b, Ahmad b. Sâ‘id en el Kitâb al-ta 'rîf bi-tabaqât al-umam ${ }^{47}$ : Aristóteles llevó a término la filosofía griega; fue el sello de sus sabios y el príncipe de sus hombres doctos. Fue el primero que separó el arte de la demostración de las restantes artes lógicas, pues le dio forma por medio de las tres figuras y la estableció como el instrumento de las ciencias teóricas, hasta el punto de que se le da el sobrenombre de "autor de la lógica". En todas las ciencias filosóficas tiene libros excelentes, universales y particulares. Los particulares son sus epístolas, de las que se puede aprender una sola idea. De los libros universales unos son mnemónicos cuya lectura sirve para recordar los conocimientos que ya se saben; son setenta libros que compuso para Eukairos. Otros son escritos propedéuticos, que estudian tres cosas: la filosofía, sus aplicaciones y el instrumento empleado en filosofía y en las otras ciencias.

De los libros que versan sobre la filosofía, unos tratan de las matemáticas, otros de la física y otros de la teología. De los libros que versan sobre filosofía, unos tratan de las matemáticas, otros de la física y otros de la teología (al-'ulûm al-ilâhiyya). Los libros que tratan de las matemáticas son Sobre la óptica, Sobre las líneas y Sobre la mecánica. De los libros que versan sobre la física, unos son aquellos en que se estudia lo que es propio de cada una de las cosas naturales y otros son aquellos en los que se estudia lo que es común a todas las cosas naturales. El libro en el que estudia lo que es común a todas las cosas naturales es el llamado Física; este libro da a conocer el número de los principios de todas las cosas, lo que es como los principios, las cosas que siguen a los principios y las cosas que se asemejan a las que siguen a los principios. Los principios son la materia y la forma; lo que es como los principios no es principio en realidad, sino casi, como la privación. Lo que sigue a los principios es el tiempo y el lugar; lo que se asemeja a lo que sigue a los principios es el vacío $\mathrm{y}$ el infinito.

De los libros que versan sobre lo que es propio de cada una de las cosas naturales, algunos tratan de las cosas que no tienen generación y otros de las cosas que se generan. Aquellos que versan sobre las cosas que no tienen generación son aquellas cosas que se estudian en los dos primeros libros de su tratado Sobre el cielo y el mundo. Aquellos que versan sobre las cosas que se generan, unos dan a conocer lo común y otros lo propio. De los que dan a conocer lo común, unos tratan de los cambios y otros de los movimientos. Los cambios son estudiados en su libro Sobre la generación y la corrupción; los movimientos, en los dos últimos libros de Sobre el cielo y el mundo. De los que dan a conocer lo propio, unos versan sobre las cosas simples y otros sobre las cosas compuestas; las cosas simples son estudiadas en sus

\footnotetext{
${ }^{47}$ Ya citado antes. Es su Libro de las categorias de las naciones, trad. F. Maíllo Salgado, Madrid, Ed. Akal, 1999.
} 
Meteorológicos; de los que versan sobre las cosas compuestas, unos describen la totalidad de las cosas compuestas y otros describen las partes de las cosas compuestas. La descripción de la totalidad de las cosas compuestas está en sus libros Sobre los animales y Sobre las plantas; la descripción de las partes compuestas está en sus libros Sobre el alma, Sobre el sentido y el sensible, Sobre la salud y la enfermedad y Sobre la juventud y la vejez.

Los libros de Teología son sus trece libros que están en su obra Metafísica (Mâ ba'd al-tabî̀'a).

Los libros que versan sobre la práctica de la filosofía, unos versan sobre la reforma de las costumbres del alma y otros sobre la política. Los que versan sobre la reforma de las costumbres del alma son su gran libro que escribió para su hijo y su pequeño libro que también redactó para su hijo y titulado $A$ Eudemo. De los que versan sobre la política, unos tratan del gobierno de las ciudades y otros del gobierno de las casas.

En cuanto a las obras sobre el instrumento utilizado en las ciencias filosóficas, son los ocho libros de lógica ${ }^{48}$, en cuya composición ninguno de los sabios le ha aventajado y en cuya elaboración nadie le había precedido. Aristóteles mismo recuerda esto al final del sexto de ellos, Refutaciones Sofísticas, donde dice: "En lo que concierne al arte de la lógica y a la construcción de los silogismos, no hemos encontrado nada original que fuera anterior a lo que hemos establecido; nos hemos dedicado a ello tras un gran esfuerzo y una larga fatiga. Aunque hemos creado y hemos inventado este arte, la hemos fortificado en su dirección y hemos reconstruido sus orígenes. No encontramos nada más que se le pueda añadir, tal como sí sucede en los principios de las otras artes; sin embargo, ella es completa y perfecta, sólidos sus cimientos, firmes sus bases, consolidada su estructura, sus fines son conocidos y sus resultados son evidentes. Se le han antepuesto pilares que facilitan su comprensión, puntales que la consolidan. Quien tal vez se aproveche de este arte después de nosotros, que perdone las deficiencias que pueda hallar, que su gratitud considere las fatigas y que tenga en cuenta el importante favor y los descubrimientos hechos. Quien hace un esfuerzo, debe ser disculpado" 49

Dice Abû Naîr al-Fârâbî que Aristóteles estableció las ocho partes [59] de la lógica, cada una de ellas en un libro... ${ }^{50}$.

\footnotetext{
${ }^{48}$ Hay que recordar que, siguiendo una tradición antigua, los árabes tuvieron como libros de lógica, además del Organon, la Retórica y la Poética.

${ }^{49}$ Hasta aquí el texto copiado de Sâ‘id, trad. citada, pp. 66-68.

${ }^{50}$ Sigue el texto que al-Fârâbî consagra a la lógica en su Ihsîâ' al- 'ulûm, El catálogo de las ciencias, edición del texto árabe, con traducción castellana y edición de la traducción latina medieval por A. González Palencia, Madrid-Granada, C.S.I. C., 20 ed. 1953, pp. 47-54 del texto árabe, pp. 32-37 de la traducción castellana. Las variantes existentes entre el pasaje copiado por Usaybi‘a y la edición de alFârâbî son mínimas y no alteran el sentido del texto
} 
[60]... Dice Ptolomeo en su libro a Gallus sobre la vida de Aristóteles: Cuando a Aristóteles le llegó la hora de la muerte, ordenó este testamento que nosotros vamos a citar... ${ }^{51}$.

\footnotetext{
${ }^{51}$ Sigue el testamento, idéntico a los textos de Ibn al-Nadîm e Ibn al-Qiftî. A continuación sigue una historia, tomada del Kitâb nawâdir al-falâsifa de Hunayn b. Ishâq sobre el origen de las escuelas de filosofía en Grecia y luego continúa con los dichos y sentencias de Aristóteles, para finalizar con un catálogo de sus libros. Sobre algunos de estos dichos de Aristóteles cf. R. Ramón Guerrero: “"Castigos» de Aristóteles en los 'Uyûn al-anbâ' de Ibn Abî Usaybi 'a", Revista Española de Filosofía Medieval, 10 (2003) 139-146.
} 